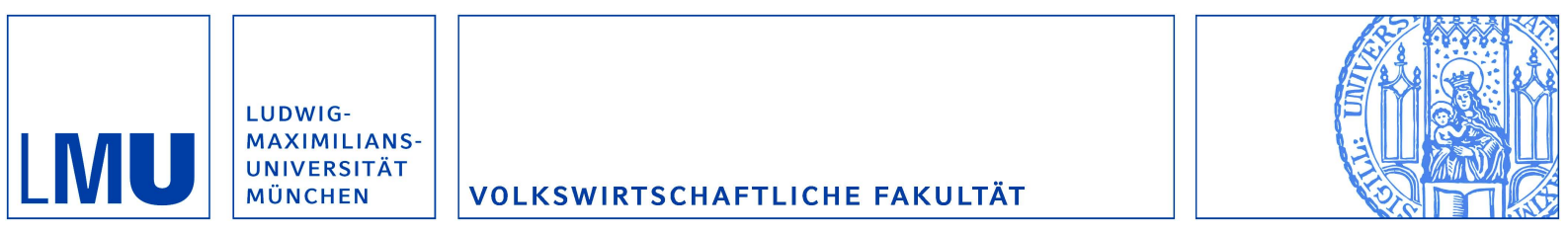

Feist, Holger:

The Enlargement of the European Union and the Redistribution of Seigniorage Wealth

Munich Discussion Paper No. 2001-4

Department of Economics

University of Munich

Volkswirtschaftliche Fakultät

Ludwig-Maximilians-Universitäł München

Online at https://doi.org/10.5282/ubm/epub. 16 


\title{
The Enlargement of the European Union and the Redistribution of Seigniorage Wealth
}

\author{
HOLGER FEIST ${ }^{*}$ \\ Princeton University and CESifo
}

\begin{abstract}
In the course of the EU enlargement process, the participation of accession countries in the European Monetary Union might lead to a significant redistribution of seigniorage wealth if current regulations prevail. In general, accession countries will be winners from this redistribution, for example Poland with 12.9 billion euros, Romania with 9.9 billion euros or Hungary with 3.3 billion euros. Correspondingly, the current member countries of the European Union face costs of 35.3 billion euros in total, the biggest part of which has to be borne by Germany.
\end{abstract}

Keywords: European Currency Union, Transition Economies, European Integration, Central Banks, Seigniorage

JEL Code: $\quad$ E 58, F33, P33

\footnotetext{
* Address: Holger Feist, Princeton University, 448 Robertson Hall, Princeton NJ 08540-1013 (U.S.A.), E-Mail: hfeist@wws.princeton.edu, Web: www.princeton.edu/ hfeist.
} 


\title{
The Enlargement of the European Union and the Redistribution of Seigniorage Wealth
}

\author{
HOLGER FEIST
}

\section{Introduction}

The enlargement of the European Union (EU), primarily to countries which are still in a process of transition from planned to market economies, is one of the greatest endeavors the continent has ever undertaken. Currently, the EU commission officially recognizes 13 countries in central and eastern Europe as candidates for accession. Twelve of them have started their formal accession negotiations, namely Bulgaria, Cyprus, the Czech Republic, Estonia, Hungary, Latvia, Lithuania, Malta, Poland, Romania, the Slovak Republic and Slovenia. The present paper focuses on these twelve countries which have already met the Copenhagen criteria, a prerequisite to becoming EU members. ${ }^{1}$ Currently, these countries are running a well-defined pre-accession program, while the EU carries out institutional reforms necessary to be in a position to accept the new member states as from 2003 on.

\footnotetext{
${ }^{1}$ Turkey, also an official candidate for accession since the Helsinki European Council on 10 and 11 December 1999, still has to meet the conditions to be fulfilled before negotiations will be taken up. As laid down at the Copenhagen European Council in June 1993, these criteria require: a.) the stability of institutions guaranteeing democracy, the rule of law, human rights, and the respect for and protection of minorities; b.) the existence of a functioning market economy as well as the capacity to cope with competitive pressure and market forces within the EU; and c.) the ability to take on the obligations of membership, including adherence to the aims of political unification, as well as economic and monetary union (cf. European Union, 1999, p. 2).
} 
In the monetary field, it is clear from the Copenhagen criteria that adherence to the aim of European Monetary Union (EMU) is one of the duties involved in the membership process. There will be no opt-out clauses for the new members, as there were for the United Kingdom and for Denmark when EMU was first created. Becoming an EU member automatically implies a commitment to finally adopting the Euro. Accession countries will initially participate in EMU with the status of a member state with a derogation, but they will have to prepare themselves for full participation. These efforts toward convergence will be assessed at least once every two years, and a country will finally become a full member of the EMU and adopt the Euro as its currency. ${ }^{2}$ The economics literature guides this process mainly by concentrating on issues of central bank independence (see, for instance, Radzyner and Riesinger, 1997, Wagner, 1999, or Cukierman, Miller and Neyapti, 2000) or in analyzing the implications of the Euro for the transition process of the economies (see Koehler and Wes, 1999).

However, full membership in EMU involves one further issue, which is both crucial and often neglected. As a matter of fact, monetary union is not only about the quality of the common currency, about money supply and price stability. It is also about sharing seigniorage profits. Central banks earn interest by lending their money to the private sector at the market rate. In doing so over a long period of time, they have steadily been accumulating interest-bearing assets while expanding their respective monetary base. These assets are now stocks of historic seignorage wealth, generating a constant annual stream of returns that helps finance government budgets. With the original creation of EMU, seigniorage wealth was redistributed between original member countries. This redistribution was noted by Remsperger (1996), and then studied

\footnotetext{
${ }^{2}$ Note that in contrast to the original creation of EMU, the convergence criteria stated in the Treaty on European Union ("Maastricht criteria") are not a prerequisite for joining the EMU (see European Central Bank 2000, p. 46).
} 
extensively by Sinn and Feist $(1997,2000)$ as well as by Gros (1998). With EU enlargement, a further round of seigniorage redistribution will begin. On the one hand, present non-member countries will have to give up their national seigniorage wealth with their accession to EMU to be socialized among all member countries. On the other hand, these countries will receive a well-defined share of the common pool.

Once this problem is clearly laid out in the following section, the obvious question is easily seen: who will win and who will lose from the redistribution of seigniorage wealth through EU enlargement? The answer will be provided in two steps, taking first the perspective of the new member countries, then focussing on current EMU member states. In both cases, actual gains and losses will be calculated. Since in effect, the overall outcome will result in a huge net wealth transfer from the old to the new member countries, the concluding remarks in the last section question whether this amount of redistribution is intended by government officials, and if not, how it could be avoided. But for now, back to a more specific definition of the problem.

\section{Seigniorage Wealth and Seigniorage Redistribution}

The theoretical concept of seigniorage wealth is discussed at length in Sinn and Feist (2000), but its core is based on a simple idea. A central bank essentially makes profits because it is entitled to provide the private sector with legal tender. While the assets obtained in exchange for it are interest-bearing, the central bank does not pay interest on the currency it issued. ${ }^{3}$ This discrepancy results in a flow of central bank profits which helps the government to finance its budget year after year. If a nation decides whether or

\footnotetext{
${ }^{3}$ It does not have to do so, since it is the monopoly supplier of the currency in the country and individuals have no choice.
} 
not to join a monetary union, hence to give up its monetary authority, it also foregoes this entire flow. By definition, the present value of this profit flow is equal to the market value of assets held by the central bank as a counterposition to its currency. Therefore, in economic terms it is justifiable to regard the waiving of the profit flow due to monetary union as foregoing the assets backing the currency circulation. These assets are a new member country's contribution to the common pool of seigniorage wealth. ${ }^{4}$ The overall effect of full EU enlargement would be an increase in seigniorage wealth from 406.8 billion euros to 429.3 billion euros, representing a $5.5 \%$ growth.

Contributions of individual countries differ, of course, as can be seen in Figure 1 which shows how much national currency is currently being used, and therefore how much seigniorage wealth is being transferred to the common pool.

\footnotetext{
${ }^{4}$ In a legal sense, only the future interest income generated by seigniorage wealth will be pooled within the Eurosystem, and the national central banks will remain the legal owners of the assets backing the monetary base. However, from an economic point of view, the socialization of an asset's return is the same as the socialization of the asset itself (see the detailed discussion in Sinn and Feist, 2000).
} 


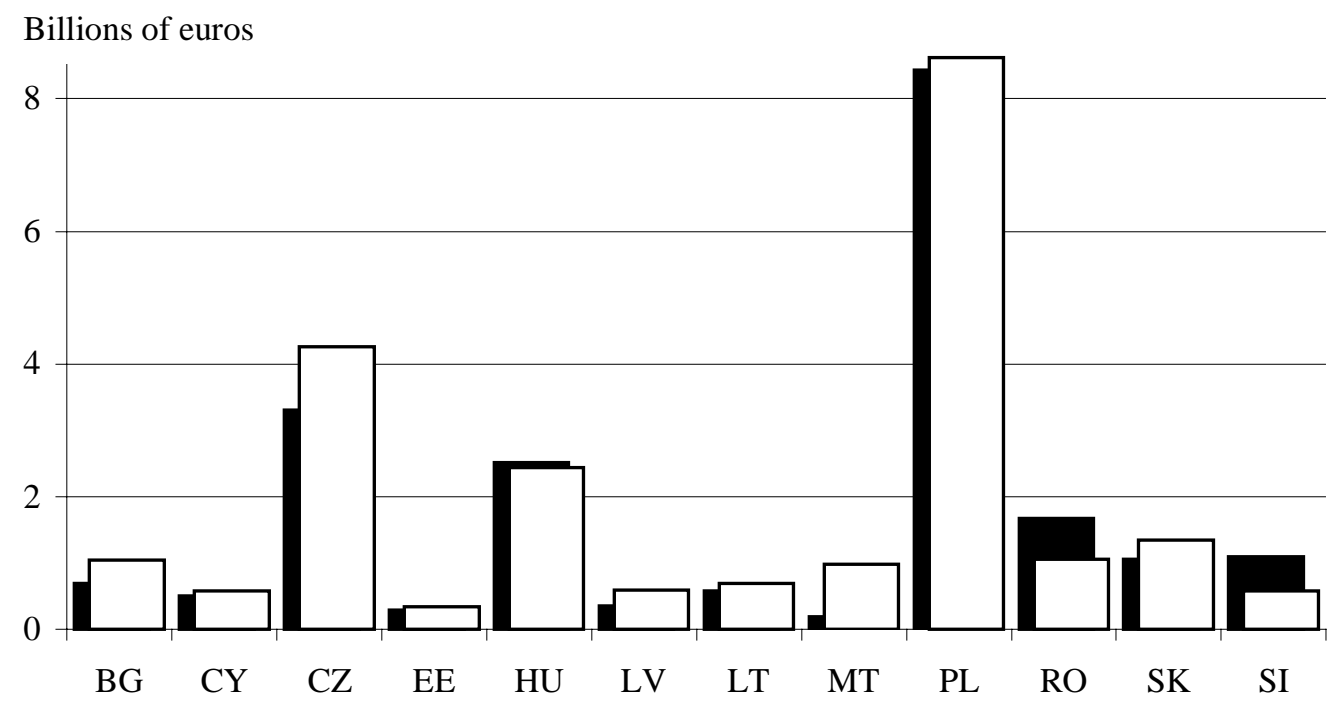

Figure 1: Currency in Accession Countries. Notes: Billions of euros, data as of 31 December 1998. BG - Bulgaria, CY - Cyprus, CZ - Czech Republic, EE - Estonia, HU - Hungary, LV - Latvia, LT Lithuania, MT - Malta, PL - Poland, RO - Romania, SK -Slovak Republic, SI - Slovenia. Source: International Monetary Fund (2000), International Financial Statistics, March, Washington, D.C.

Poland, which is also the largest country, contributes most with 8.6 billion euros, followed by the Czech Republic with 4.3 billion euros and Hungary with 2.4 billion euros. To provide a better understanding of these numbers, the black shadows of the bars state a fictitious amount of currency which would circulate in the country if it used just as much money per unit of GDP as the EU countries do on average. Obviously, in most countries there is more currency in circulation than there were in western-type economies with the same gross domestic product, and the numbers prove this visual inspection to be true. While in the EU, 5.4 euros are in circulation on average per hundred euros of gross domestic product, the average of all accession countries is 5.9 per cent.

Of course, contributing national seigniorage wealth which stems from the currency is only one side of the coin for a country. For these contributions, each country in turn earns a share of the common profit flow resulting from the pooled assets. This share does not necessarily correspond to the share of the contributions, and to the extent 
that these two shares do not match one another, seigniorage wealth is redistributed. In general, there will be a difference because according to the Statute of the European System of Central Banks and the European Central Bank (ECB), what a country receives from the pool is not determined by its amount of currency, but rather by its capital share in the ECB. ${ }^{5}$ The capital share is in turn determined by the average of a country's shares in EU aggregate population and gross domestic product, a combination index that might serve as an idiosyncratic single measure of country size. Figure 2 provides an illustration of what individual countries receive and what they contribute.

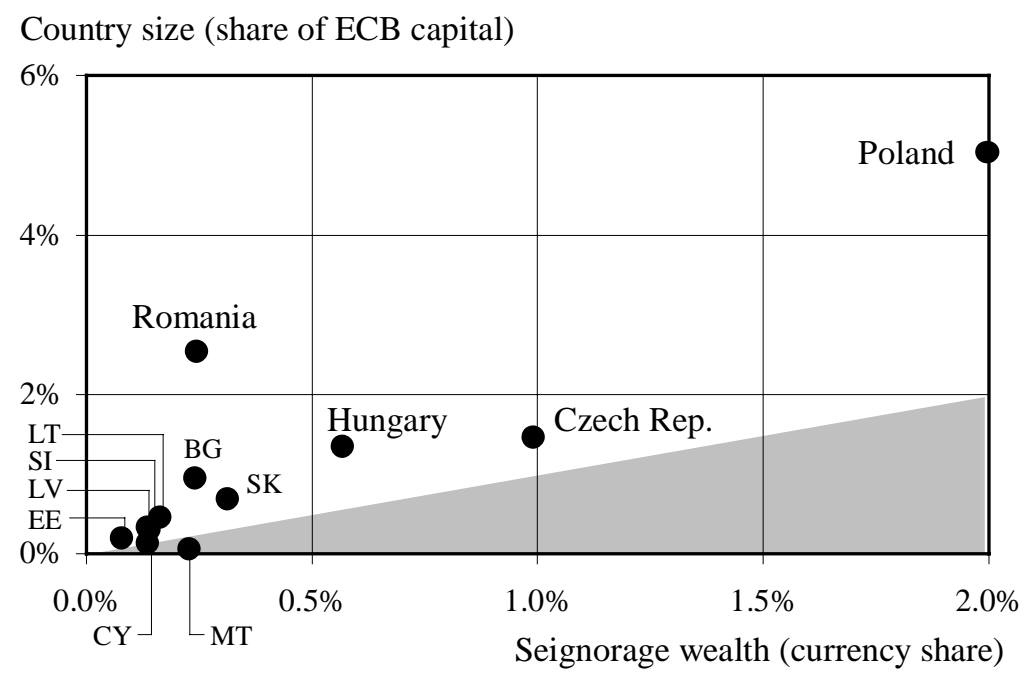

Figure 2: Seigniorage Wealth and Country Size. Notes: Billions of euros, data as of 31 December 1998. BG - Bulgaria, CY - Cyprus, EE - Estonia, LV - Latvia, LT - Lithuania, MT - Malta, SK -Slovak Republic, SI - Slovenia. Source: International Monetary Fund (2000), International Financial Statistics, March, Washington, D.C.

\footnotetext{
${ }^{5}$ The initial endowment of ECB equity capital has little function other than to establish a stake in the seigniorage profit. With just $€ 5$ billion the total capital endowment is tiny relative to seigniorage wealth. Furthermore, the interest it generates will be distributed among the members of the Eurosystem in proportion to the capital contribution, so that no redistribution will take place here.
} 
The seigniorage wealth each country contributes is noted on the horizontal axis and the country size, which determines what they receive, on the vertical axis. Therefore, countries located in the upper left of this diagram win from the distribution, while countries located in the shaded triangle in the lower right lose. It turns out that most of the countries considered as candidates for EU enlargement win. Only Cyprus and Malta lose, but their proximity to the origin of the diagram indicates that both their contributions and their receipts are relatively small.

The following sections explore in greater detail how much is at stake for indivdiual countries. First, a calculation of precisely how much the accession countries will actually earn from the redistribution of seigniorage wealth is made. Then, the loss of individual EU countries is calculated.

\section{Redistributive Effects for the Economies in Transition}

As shown in the previous section, distributing the pooled seigniorage wealth according to a key other than that measuring the individual contributions of the participating countries permits some countries to win, while others lose. Now that the mechanism of redistribution has been properly discussed, the amount of this redistribution may be calculated. In the following, the situation is presented from the perspective of the accession countries. Section 4 will then highlight the point of view of current member countries.

In Table 1, the shares of seigniorage wealth being contributed and received by each country are stated, together with the resulting gains or losses. The situation refers to the point of time where the most complete data is available, which is 31 December 1998. Only the GDP figure of Poland and the monetary figures of Hungary are still estimates at this point of time, while the figures for all other countries have been officially confirmed. 
Columns [1] and [2] list each country's currency circulation in absolute and relative terms, representing the amounts of seigniorage wealth contributed to the common pool. These figures were presented graphically in Figure 1, and discussed in more detail above.

In the following three columns, the prospective country's share in the capital of the European Central Bank is calculated as mandated by Article 32 of the Statute. It is assumed that all present EU member countries are also full members of the Eurosystem at the very point of time when the first accession country becomes full member. ${ }^{6}$ The capital share in column [5], which determines the receipts from seigniorage profits, results from the arithmetic average of population and GDP shares in columns [3] and [4]. Note that these latter two measures of country size differ significantly among the accession countries, reflecting the differences in their per capita income. So far, the table presents the calculations necessary to arrive at Figure 2, which essentially compares the relative contributions and receipts in columns [2] and [5].

Most interestingly, the amount of the gains and losses resulting from the redistribution of seigniorage wealth are stated in columns [6] and [7]. The gain of a country is the difference between what it contributes and what it receives, so it may be calculated as the difference of the country's entries in columns [2] and [5], multiplied by the amount of seigniorage wealth in the common pool, totalling 429.3 billion euros.

\footnotetext{
${ }^{6}$ This assumption presumes that Sweden and the two opt-out countries, Denmark and the United Kingdom, have joined the monetary union before the first accession country does. Of course, alternative scenarios are conceivable, but this would not much change the result. More technically, the Statute mandates a five-year average of population and GDP shares preceding the year of accession. Here, only the 1998 shares are taken into account since they provide the information which comes closest to the point of time when the accession to monetary union will actually take place.
} 


\begin{tabular}{|c|c|c|c|c|c|c|c|}
\hline \multirow{3}{*}{$\begin{array}{l}\text { Seigniorage wealth... } \\
\text { all amounts } \\
\text { in euros }\end{array}$} & \multirow{2}{*}{\multicolumn{2}{|c|}{$\frac{\ldots \text { contributed }}{\text { Currency }}$}} & \multicolumn{3}{|c|}{$\ldots$ received } & \multirow{2}{*}{\multicolumn{2}{|c|}{$\frac{\ldots \text { redistributed }}{\text { Gain or loss }}$}} \\
\hline & & & \multirow{2}{*}{$\begin{array}{c}\text { Population } \\
\text { share } \\
{[3]}\end{array}$} & \multirow{2}{*}{$\begin{array}{c}\text { GDP } \\
\text { share } \\
{[4]}\end{array}$} & \multirow{2}{*}{$\begin{array}{l}\text { Capital } \\
\text { share } \\
{[5]}\end{array}$} & & \\
\hline & $\begin{array}{c}\text { billions } \\
\text { [1] }\end{array}$ & $\begin{array}{c}\text { share } \\
{[2]}\end{array}$ & & & & $\begin{array}{c}\text { billions } \\
{[6]}\end{array}$ & $\begin{array}{c}\text { per capita } \\
\text { [7] }\end{array}$ \\
\hline Bulgaria & 1.0 & $0.2 \%$ & $1.7 \%$ & $0.2 \%$ & $0.9 \%$ & 3.0 & 364 \\
\hline Cyprus & 0.6 & $0.1 \%$ & $0.1 \%$ & $0.1 \%$ & $0.1 \%$ & 0.0 & -22 \\
\hline Czech Republic & 4.3 & $1.0 \%$ & $2.1 \%$ & $0.8 \%$ & $1.5 \%$ & 2.0 & 195 \\
\hline Estonia & 0.3 & $0.1 \%$ & $0.3 \%$ & $0.1 \%$ & $0.2 \%$ & 0.5 & 321 \\
\hline Hungary & 2.4 & $0.6 \%$ & $2.1 \%$ & $0.6 \%$ & $1.3 \%$ & 3.3 & 331 \\
\hline Latvia & 0.6 & $0.1 \%$ & $0.5 \%$ & $0.1 \%$ & $0.3 \%$ & 0.7 & 277 \\
\hline Lithuania & 0.7 & $0.2 \%$ & $0.8 \%$ & $0.1 \%$ & $0.5 \%$ & 1.2 & 337 \\
\hline Malta & 1.0 & $0.2 \%$ & $0.1 \%$ & $0.0 \%$ & $0.1 \%$ & -0.7 & $-1,869$ \\
\hline Poland & 8.6 & $2.0 \%$ & $8.1 \%$ & $2.0 \%$ & $5.0 \%$ & 12.9 & 334 \\
\hline Romania & 1.1 & $0.2 \%$ & $4.7 \%$ & $0.4 \%$ & $2.5 \%$ & 9.9 & 438 \\
\hline Slovak Republic & 1.3 & $0.3 \%$ & $1.1 \%$ & $0.2 \%$ & $0.7 \%$ & 1.6 & 296 \\
\hline Slovenia & 0.6 & $0.1 \%$ & $0.4 \%$ & $0.3 \%$ & $0.3 \%$ & 0.9 & 431 \\
\hline European Union & 406.8 & $94.7 \%$ & $77.9 \%$ & $95.2 \%$ & $86.5 \%$ & -35.3 & -94 \\
\hline Total & 429.3 & $100.0 \%$ & $100.0 \%$ & $100.0 \%$ & $100.0 \%$ & 0.0 & - \\
\hline
\end{tabular}

Table 1: Redistributive Effects for Accession Countries. Notes: Data as of 31 December 1998. Source: International Monetary Fund (2000), International Financial Statistics, March, Washington, D.C.

The results are striking. Most accession countries are winners in the redistribution of seigniorage wealth. Since they are relatively small compared to the EU, the total gains may not look all that impressive, amounting to between 0.5 billion euros for Estonia and 3.3 billion euros for Hungary. Only the Romanian and the Polish gains stand out, with 9.9 and 12.0 billion euros, respectively. However, the gains are quite important from a national point of view, which is emphasized in the per-capita figures. The average Czech citizen wins least with 195 euros, the average Romanian most with 438 euros, and most countries carryper-capita gains of about 300 euros.

As noted above, only the two Mediterranean accession countries - Malta and Cyprus - are losers. Since these are tiny island countries, their absolute loss is 
correspondingly small, and the same is true for the average Cypriot's loss of 22 euros. However, the average Maltese has to pay 1,869 euros for the right to participate in the monetary union, ${ }^{7}$ which is by far the highest per-capita loss from the redistribution of seigniorage wealth ever calculated for a country. ${ }^{8}$

In interpreting these results, it is important to note again that these figures are not annual values, but that they describe the once-and-for-all gain or loss of seigniorage wealth which is associated with the participation in EMU. But these are precisely the figures best suited to describe gains or losses from the redistribution of seigniorage wealth, for a country facing the decision whether to join once and for all, or not to join at all.

Given that the vast majority of accession countries are winners, it is clear that someone has to bear the burden. As can be seen one line above the bottom of the list, the current member states of the European Union have to face the fact that full EU enlargement will cost them 35.3 billion euros of their accumulated seigniorage wealth in total. This is a higher price than the one Germany had to pay for monetary union in the first place. The average EU citizen has to pay 94 euros for full enlargement. But do Europeans feel themselves to be Europeans yet? The following section calculates the costs per current member country.

\footnotetext{
${ }^{7}$ Note that throughout the text, "paying", as well as "winning" and "losing", only refers to gains or losses resulting from the redistribution of seigniorage wealth. As stated in the introduction, there are of course other important costs and benefits from EU enlargement, which are not addressed here, but which are surveyed extensively in the literature (see e.g. Baldwin, Francois, and Portes, 1997).

${ }^{8}$ Up to now, Germany had to suffer the highest per-capita loss with 358 euros, followed by Spain with 281 euros and Austria with 222 euros (cf. Sinn and Feist 2000, p. 11).
} 


\section{Effects on Current Members}

Calculating the costs which EU enlargement imposes on current member countries due to loss of relative seigniorage wealth is straightforward. The 35.3 billion euros which accession countries gain are distributed among all the countries which form the monetary union at the point of time of accession. Again, it is assumed that Denmark, Sweden and the United Kingdom will have joined before the accession countries do. Table 2 breaks the EU losses down to the national level.

For current member countries, the enlargement means a shrinking share in the ECB capital, which defines their receipts from the common seigniorage pool. By comparison of columns [1] and [2], it is easy to verify that this is true for each country. This is unsurprising since the accession countries will hold a combined share of $13.5 \%$ of the ECB capital, meaning that the other countries have to forego some of their share. However, the current member countries also benefit from the accession countries because those bring their combined seigniorage wealth into the common pool. At the bottom line of the columns, total seigniorage wealth can be seen to rise from 406.8 billion euros before accession to 429.3 billion euros after accession. But yet, the net effect for current member countries is negative. Subtracting each country's seigniorage wealth before accession from the one after yields as a result the net effect due to accession. It is reported as total numbers in column [3], and as per-capita values in column [4].

The figures validate that the biggest shareholders in the European Central Bank are also the biggest losers in absolute terms. Germany loses 7.7 billion euros, France 5.5 billion euros, and Italy 5.4 billion euros. If the United Kingdom joins EMU, it will lose 5.6 billion euros through enlargement. Note that in per-capita terms, there is hardly any difference among current member countries. This is due to the fact that losses are shared according to ECB capital share, which is one half determined by the population share - the other half being determined by the GDP share -, and that per-capita GDP is 
relatively equal among current member countries. Richer countries are slightly favored through this setting, but overall, national deviations from the 94 euro which accession costs the average European are hardly visible. Remember that the average accessioncountry citizen gains 333 euros in turn.

\begin{tabular}{|c|c|c|c|c|c|c|c|c|}
\hline \multirow{3}{*}{$\begin{array}{l}\text { All amounts } \\
\text { in euros }\end{array}$} & \multicolumn{2}{|c|}{ Seigniorage Wealth } & \multicolumn{6}{|c|}{ Gain or loss due to ... } \\
\hline & \multirow{2}{*}{$\begin{array}{c}\text { Before } \\
\text { accession } \\
{[1]}\end{array}$} & \multirow{2}{*}{$\begin{array}{c}\text { After } \\
\text { accession } \\
{[2]}\end{array}$} & \multicolumn{2}{|c|}{ Accession } & \multicolumn{2}{|c|}{ EMU 1999} & \multicolumn{2}{|c|}{ Overall } \\
\hline & & & $\begin{array}{c}\text { total, bn } \\
{[3]}\end{array}$ & $\begin{array}{c}\text { per capita } \\
{[4]}\end{array}$ & $\begin{array}{c}\text { total, bn } \\
{[5]}\end{array}$ & $\begin{array}{c}\text { per capita } \\
{[6]}\end{array}$ & $\begin{array}{c}\text { total, bn } \\
{[7]}\end{array}$ & $\begin{array}{c}\text { per capita } \\
{[8]}\end{array}$ \\
\hline Austria & $2.4 \%$ & $2.1 \%$ & -0.8 & -94 & -2.7 & -339 & -3.5 & -433 \\
\hline Belgium & $2.9 \%$ & $2.5 \%$ & -1.0 & -94 & -0.9 & -88 & -1.9 & -182 \\
\hline Finland & $1.5 \%$ & $1.3 \%$ & -0.5 & -94 & +2.9 & +574 & +2.5 & 480 \\
\hline France & $16.5 \%$ & $14.4 \%$ & -5.5 & -94 & +23.5 & +402 & +18.0 & 308 \\
\hline Germany & $23.9 \%$ & $20.8 \%$ & -7.7 & -94 & -41.4 & -505 & -49.2 & -599 \\
\hline Greece & $2.1 \%$ & $1.8 \%$ & -1.0 & -96 & +1.7 & +166 & +0.7 & 70 \\
\hline Ireland & $1.0 \%$ & $0.9 \%$ & -0.3 & -94 & +0.2 & +50 & -0.2 & -45 \\
\hline Italy & $14.7 \%$ & $12.7 \%$ & -5.4 & -95 & -4.7 & -82 & -10.2 & -177 \\
\hline Luxembourg & $0.2 \%$ & $0.1 \%$ & -0.0 & -92 & +0.5 & $+1,287$ & +0.5 & 1,194 \\
\hline Netherlands & $4.4 \%$ & $3.8 \%$ & -1.5 & -94 & -0.8 & -55 & -2.3 & -149 \\
\hline Portugal & $2.0 \%$ & $1.6 \%$ & -0.9 & -96 & +3.4 & +343 & +2.5 & 248 \\
\hline Spain & $8.6 \%$ & $7.2 \%$ & -3.7 & -95 & -15.8 & -403 & -19.6 & -499 \\
\hline Denmark & $1.8 \%$ & $1.5 \%$ & -0.5 & -93 & +2.5 & +472 & +2.0 & 378 \\
\hline Sweden & $2.4 \%$ & $2.1 \%$ & -0.8 & -94 & +2.1 & +237 & +1.3 & 143 \\
\hline United Kingdom & $15.9 \%$ & $13.7 \%$ & -5.6 & -94 & +29.6 & +503 & +24.1 & 408 \\
\hline Accession Area & - & $13.5 \%$ & +35.3 & +333 & - & - & +35.3 & +333 \\
\hline Total & 406.8 & 429.3 & 0.0 & - & 0.0 & - & 0.0 & - \\
\hline
\end{tabular}

Table 2: Redistributive Effects for Current Member Countries. Notes: Data as of 31 December 1998. Source: International Monetary Fund (2000), International Financial Statistics, March, Washington, D.C.

Proceeding one step further, one might ask how this effect changes the gains or losses which current member countries incurred when they first founded or joined EMU, independent of enlargement considerations. These effects may be calculated using the framework described above, and for various membership scenarios, which has been 
performed in the literature cited above. The case of full monetary union among all current EU members is the point of departure relevant to the problem presented here, and these gains are explicitly stated in columns [5] and [6], for the first time with final data. The common result of this kind of calculation in the literature prevails here, too: France and the United Kingdom are the chief winners in full monetary union with 23.5 billion billion and 29.6 billion euros, respectively. The average Frenchman gains 402 euros from full monetary union; the average Englishman 503 euros. On the other hand, Germany is the big loser with 41.4 billion euros in total or 505 euros per capita.

Adding up the figures in columns [3] and [5] leads to the national overall effect of both steps, the creation of full monetary union in the first place and enlargement by the accession countries thereafter. As may be seen from columns [7] and [8], accession makes a difference even for the big countries. The French gains shrink by $23.4 \%$ to 18.0 billion euros or 308 euros per capita, the British by $18.9 \%$ to 24.1 billion euros or 408 euros per capita. German losses increase by $18.6 \%$ through EU enlargement, now totalling 49.2 billion euros or 599 euros per capita. Ireland, which was a winner in the case of full monetary union, becomes a loser if the accession countries join.

The method employed here is a conservative method of calculating the redistributive effects in many ways. One way is the application of the stock approach to measure seigniorage wealth. It is less arbitrary than a flow approach since it does not involve any guesswork in future monetary develpoments, nor does it require a forecast of future interest rates for discounting purposes. It offers a clear-cut calculation of the redistributive effects based on a ceteris paribus assumption. Of course, structural changes in payment behaviours would change the result. Increased use of electronic cash, for example, would reduce the currency circulation in the future, and therefore it would be less expensive for a country to give up the national monopoly to issue coins and banknotes. However, this will only have a redistributive effect if the developments differ among countries. This issue may be worth future research, but for the purposes of this 
paper the assumption of unchanged payment habits, which the stock approach implicitly takes, seems in order to avoid confusion from assumptions and forecasts of changing payment habits.

\section{Conclusions}

It has been shown in this paper that EU enlargement might lead to a considerable redistribution of seigniorage wealth among current members and accession states. Percapita gains for accession states will average 333 euros, while the average citizen of a current member state will lose 94 euros. These figures are not negligible, as the total gains for Poland (12.0 billion euros), for Bulgaria (9.9 billion euros), and for Hungary (3.3 billion euros) demonstrate. The losses faced by Germany total 7.7 billion euros, followed by 5.5 billion euros in France and 5.6 billion euros in the United Kingdom.

The case for this paper is not to suggest any efficiency or distributive argument in favor of a different treatment of seigniorage wealth. This decision is up to the policymakers. It may well be that EU enlargement is worth the price of redistributing part of their seigniorage wealth for the current member countries. However, it is important to take note of the Eurosystem's profit-sharing rules and to clearly understand the automatic redistribution mechanism involved. Once a country with a relatively low currency circulation - as measured in equal parts against population and GDP - joins the monetary union, the current member countries of the monetary union will automatically lose seigniorage wealth.

The lesson could have been learnt with the creation of European Monetary Union itself, when great amounts of seigniorage wealth were redistributed, probably without the 
full understanding of all involved parties. ${ }^{9}$ Then, it was too late for the losing parties to renegotiate the regulations concerning seigniorage wealth, even if they had wished so. Since this would basically have meant a renegotiation of the Treaty on the European Union, too much was at stake.

In this respect, the two problems differ. With EU enlargement, policy-makers do have the time to decide whether they intend and like the redistribution of historically accumulated seigniorage wealth. If they oppose the idea, they may seriously reconsider the rules leading to the automatic redistribution mechanism discussed here. All it would take is to resort to the grandfathering solution suggested in the literature by Sinn and Feist $(1997,2000)$ and by Gros (1998). To start with, the common central bank's profits might simply be distributed according to the initial seigniorage wealth contributed. Over time, the key might then be adjusted to distribute future growth of seigniorage wealth according to country size, as suggested in the Statute. This procedural adjustment will be necessitated by the further development of the European economies, and it might also result from a future success of the euro as a transactions currency. While historic seigniorage wealth would be exempt from redistribution, increments in seignigorage wealth would be shared among all countries by population and GDP shares. In this case, it is not yet too late to bring the rules together with the policy-makers' intents, should these two differ.

\footnotetext{
${ }^{9}$ This seems to be a fair interpretation, at least in the German case. Only after the problem was laid out properly in the academic world did the topic catch the attention of the public. The reactions are well documented in a query in the German parliament (Deutscher Bundestag, 1997), and the official statements do not imply that the authorities were aware of this redistribution from the beginning. On the contrary, they state their willingness to stress the point in further consultations with EU central banks and urge for a strengthening of the German position. The gap between the realization of the phenomenon in the academic and the political worlds is surprising.
} 


\section{References}

Baldwin, Richard E., Joseph E. Francois, and Richard Portes (1997): "The Costs and Benefits of Eastern Enlargement: The Impact on the EU and Central Europe", Economic Policy 24, 127-176.

Cukierman, Alex, Geoffrey P. Miller, and Bilin Neyapti (2000): "Central Bank Reform, Liberalization and Inflation in Transition Economies: An International Perspective," Working paper No. 19, Foerder Institute for Economic Research: Tel Aviv.

European Central Bank (2000): "The Eurosystem and the EU Enlargement Process," Monthly Report, February, pp. 39-51.

European Union (1999): Presidency Conclusions, Helsinki European Council, 10 and 11 December 1999, DOC/99/16, Brussels.

Gros, Daniel (1998): “Distributing Seignorage under EMU,” Ifo Schnelldienst No. 17-18, 29-39.

Koehler, Horst, and Marina Wes (1999): "Implications of the Euro for the Integration Process of the Transition Economies in Central and Eastern Europe," Working Paper No. 38, European Bank for Reconstruction and Development: London.

Radzyner, Olga, and Sandra Riesinger (1997): “Central Bank Independence in Transition: Legislation and Reality in Central and Eastern Europe", Focus on Transition 1, 57-90. 
Remsperger, Hermann (1996): “Umverteilung der Notenbankgewinne in der Währungsunion. Milliardenverluste für den Bundeshaushalt?," Wirtschaftsdienst der BHF-Bank, No. 181, 1-3.

Sinn, Hans-Werner, and Holger Feist (1997): "Eurowinners and Eurolosers. The Distribution of Seignorage Wealth in EMU," European Journal of Political Economy 13, 665-689.

Sinn, Hans-Werner, and Holger Feist (2000): "Seignorage Wealth in the Eurosystem: Eurowinners and Eurolosers Revisited," Working Paper No. 353, CESifo: Munich.

Wagner, Helmut (1999): "Central Bank Independence and the Lessons for Transition Economies from Developed and Developing Countries," Comparative Economic Studies $41,1-22$. 